\title{
Detection of Financial Statement Fraud: In Review of Bystander Effect, Whistleblowing and Locus of Control
}

\author{
Putu Riesty Masdiantini ${ }^{1, *}$ Sunitha Devi ${ }^{1}$ I Gusti Ayu Purnamawati ${ }^{1}$ Putu Eka \\ Dianita Marvilianti Dewi ${ }^{1}$
}

\author{
${ }^{1}$ Department of Economic and Accounting, Universitas Pendidikan Ganesha, Singaraja, Indonesia \\ *Corresponding author. Email: riesty.masdiantini@undiksha.ac.id
}

\begin{abstract}
The motive of this study is to obtain empirical evidence concerning the detection of financial assertion fraud thru the relationship bystander effect, whistleblowing, and locus of control. This study makes use of quantitative lookup the usage of an experimental approach. The pattern in this study was chosen primarily based on a non-probability technique with a purposive sampling technique, particularly 190 college students of the accounting diploma program, Faculty of Economics, The Ganesha University of Education. Students are assumed to recognize to be capable to make selections concerning fraud in financial statements and the detection of such fraud. The consequences showed that the bystander impact did not impact on the prevalence of economic statement fraud. Meanwhile, whistleblowing has an impact on the incidence of financial announcement fraud. Locus of manipulate is able to average the have an impact on of bystander impact on financial assertion fraud. However, the locus of manage variable has no longer been in a position to moderate the affect of whistleblowing on monetary statement fraud.
\end{abstract}

Keywords: Bystander effect, Financial statement fraud, Locus of control, Whistleblowing.

\section{INTRODUCTION}

In the current era of globalization, the availability of information is needed in making business decisions. As the language of business, in this case, accounting has a role in providing information for business people. A collection of important and trustworthy information by internal and external parties of the company is contained in the financial statements. Financial statements are a source of statistics involving the development of a business in a positive period. The company's monetary records contained in the stability sheet, profits statement, assertion of proprietor fairness and money float statements can be used as a foundation for making monetary decisions [1].

The importance of information content in financial statements makes managers motivated to improve company performance. This is done by managers so that the existence of the company can be mainained. But in fact, there are many cases where the company's management fails to achieve its performance targets, so that the information displayed in the financial statements is unsatisfactory for investors and company owners.
Therefore, sometimes administration is willing to make fraudulent efforts so that the information in the financial statements looks precise [2]. One of the most phenomenal examples of fraudulent financial statements is the case of fraud committed by Enron Corporation, a multinational company. The Enron case dragged public accountant Arthur Andersen who was responsible for auditing financial statements. The existence of Arthur Andersen in the vortex of the Enron case made the reputation crumbles and thrown from The Big Five of public accountants.

In Indonesia, there are several cases of fraudulent financial statements that have shocked the public because they involve well-known publicly traded companies. For example, in the case of PT Kimia Farma Tbk, where the Ministry of SOEs and Bapepam found an overstatement for in the end of December 31, 2001. In addition, fraudulent financial statements even occurred in StateOwned Enterprises (BUMN) companies engaged in the transportation sector, namely PT KAI (Indonesian Railways). Quoted from Hikmah (2017), PT. Kereta Api Indonesia (PT KAI) manipulated data in PT KAI's financial statements in 2005, where the state-owned 
company recorded a profit of Rp. 6.9 billion, despite the fact that it suffered a loss of Rp. 63 billion [3].

The movements taken via management on the presentation of information in the monetary statements are strongly influenced with the aid of the conduct that exists in every human being. This human behavior that affects accounting data becomes vulnerable to fraud. This fraud occurs because of the bystander effect, namely someone who knows there is an act of fraud but chooses to remain silent and in himself deliberately allows it or does not want to be involved in the case, which can disrupt his working position [4]. In addition, one way to prevent accounting violations so as to restore public trust is to do whistleblowing. The importance of whistleblowing in the company will act as a warning or witness for someone who commits fraudulent financial statements. Whistleblowing is an action taken by an individual or group to divulge fraud that occurs either by an agency or an individual. However, in reality there are still many employees who are reluctant to become a whistleblower even though they already have a reporting platform. The phenomenon that occurs at this time is more directed to fraud carried out in congregation [5].

This find out about refers to research related to the role of the bystander impact and whistleblowing on the occurrence of economic statement fraud [4] by modifying adding a moderating variable, namely locus of control. Locus of control is a person's self-control to act or not act [6][7]. As a result, someone with an internal locus of control is more responsible for the results of their actions or behavior towards themselves and determines for themselves what is right and wrong for behavioral guidelines [8]. In contrast, someone with an external locus of control is more responsible with other parties and situational factors, therefore they are more likely to engage in unethical [9][10].

\section{LITERATURE REVIEW \& HYPOTHESIS DEVELOPMENT}

\subsection{Theory of Planned Behavior}

Grand theory that underlies this research can be explained through the perspective of the Theory of Planned Behavior (TPB). Through this theory, it is explained that the main factor that causes the emergence of individual behavior is the intention to perform the behavior. There are three components described by the theory of planned behavior that can affect the emergence of an intention, which will then contribute to the formation of individual behavior. The three components are attitudes, subjective norms, and perceived behavioral control [11].

\subsection{Agency Theory}

Agency relationship is a contract that occurs between the manager (agent) and the owner of the company (principal) [12]. Agency theory uses three assumptions of human nature, namely: (1) humans are generally selfinterested (self-interested), (2) humans have limited thinking power regarding future perceptions (bounded rationality), and (3) humans always avoid the risk averse). Based on the assumption of human nature, managers will act opportunistically, particularly prioritizing their non-public pursuits [13].

\subsection{Financial Statements}

Financial statements are reviews that exhibit the company's monetary condition at this time or in a certain period. Usually, monetary reports are made per period, for example three months, or six months for the company's indoors interests. Meanwhile, for a wider report, it is carried out once a year. Through the financial statements, the latest position of the organization can be identified after the financial statements are analyzed [14] In practice, there are several kinds of financial reports, such as: (1) balance sheet; (2) income statement; (3) statement of owner equity; (4) cash flow statement; and (5) notes to financial statements.

\subsection{Fraud}

Fraud is a deliberate fraud that causes losses barring realizing it by way of the injured celebration and gives advantages for the perpetrators of fraud. Fraud commonly happens because of strain to commit fraud or encouragement to take advantage of current possibilities and there is a (generally accepted) justification for these moves [15].

\subsection{Bystander effect}

Bystander effect is a phenomenon when individuals do not provide assistance in an emergency when or when other people are present. Often we assume that the more people who are around an emergency event, the more people will help. However, a study states the opposite fact. The more presence of other people in an emergency event will actually reduce the tendency of individuals to provide help[16].

\subsection{Whistleblowing}

Whistleblowing is an action taken by using men and women or agencies to disclose fraud that takes place either via groups or individuals. Whistleblowing can be described as a technique that involves non-public factors and organizational social factors[17]. Whistleblowing can also be interpreted as reporting by active or nonactive members of the organization regarding violations, 
illegal or immoral actions to parties inside and outside the organization[18].

\subsection{Locus of control}

Locus of manipulate is a person's strength of mind to act or not act. Someone who has a excessive inside locus of manage believes that his conduct and movements are decided with the aid of activities in his life. People who have an interior locus of manipulate accept as actual with that they manage what takes place to them. On the other hand, human beings who have an exterior locus of manipulate be given as true with that opportunity, fate, and specific events decide what takes place in them. Someone who has an external locus of manipulate believes that what takes place to them is managed by way of exterior forces such as actual fortune, excellent fortune and opportunity.

Based on the explanation of theoretical studies and the results of previous research, the following research hypothesis can be formulated.

$\mathrm{H}_{1}$ : Bystander effect has a positive effect on financial statement fraud

$\mathrm{H}_{2}$ : Whistleblowing has a negative effect on financial statement fraud

$\mathrm{H}_{3}$ : Locus of control can moderate the influence of bystander on financial statement fraud

$\mathrm{H}_{4}$ : Locus of control can moderate the influence of whistleblowing system on financial statement fraud

\section{METHOD}

The system of lookup problems related to the detection of financial declaration fraud through the relationship bystander effect, whistleblowing and locus of manage will be examined the usage of an experimental approach. The quantitative research design makes use of an experimental method to a quasi-experimental format namely $2 \times 2$ factorial design. Participants in this find out about used college students as substitutes for personnel and corporation management.

The populace of this find out about is all students of the Faculty of Economics, The Ganesha University of Education, Accounting a degree program. The sample in this learn about was selected primarily based on a nonprobability technique with purposive sampling method so that a pattern of a hundred ninety college students was obtained. Based on the choice of sure criteria, it can be assumed that you apprehend to be capable to make choices concerning fraudulent acts in economic statements and the detection of such fraud. Research data is amassed via questionnaires and answers to instances of fraudulent financial statements.
The research hypotheses were tested by using the Two-Ways Analysis of Variance (ANOVA) test. The level of significance $(\alpha)$ used in this study was 0.05 . The research hypothesis testing was carried out with the help of the Statistical Package for the Social Sciences (SPSS) software.

The test criteria with a significance level of $5 \%$ are as follows[19].

If the significance value $>0.05$ then $\mathrm{H} 0$ is accepted If the significance value $<0.05$ then $\mathrm{H} 0$ is rejected. Before testing the hypothesis, a prerequisite test will be carried out, namely the normality test and the homogeneity test.

\section{RESULTS \& DISCUSSION}

\subsection{Research result}

\subsubsection{Normality Test}

The first step that needs to be done before carrying out statistical tests is to test the normality of the data to be studied so as not to violate the basic assumptions of the statistical tools used. The results of the normality test can be seen in the Table 1 .

Based on the above results, it can be seen that the value of Kolmogorov Smirnov is 1.162 and significant at 0.134 which means more than 0.05 . This shows that the model has a normal distribution and meets the assumption of normality.

\subsubsection{Homogeneity Test}

In addition to the data must be normally distributed, one of the requirements for hypothesis testing to be carried out is that the data must have the same homogeneity. Therefore, here are the results of the homogeneity test of the data to be tested.

Based on Table 2, it is known that the Levene's test results have a significance level of 0.430 , so what is desired is that Levene's test is not significant (probability $>0.05)$ thus the data has the same homogeneity.

\subsubsection{Hypothesis Test}

After the assumptions have been met, in this case the data comes from groups that are not interconnected, normally distributed, and have the same variance, then the hypothesis testing using Two Ways ANOVA. The Table 3 depicts the result of hypothesis testing. The results in Table 3 above are values that indicate whether the hypothesis is accepted or not, where the criteria for acceptance of a hypothesis is a significance value $<0.05$. 
Table 1. Normality Test Results

\begin{tabular}{|l|l|l|}
\hline & Asymp Sig. & Description \\
\hline FIN & 0,134 & Normal distribution \\
\hline
\end{tabular}

Source: primary data processed, 2021

Table 2. Homogeneity Test Results

\begin{tabular}{|l|l|}
\hline Levene Test (Sig.) & Description \\
\hline 0,430 & $\begin{array}{l}\text { variance between groups is the } \\
\text { same }\end{array}$ \\
\hline
\end{tabular}

Source: primary data processed, 2021

Table 3. Two Ways ANOVA Test Results

\begin{tabular}{|l|l|l|}
\hline Variable & Sig. & Description \\
\hline BYS & 0,225 & H1 Rejected \\
\hline WHI & 0,037 & H2 Accepted \\
\hline BYS*FRCASE`LOC & 0,017 & H3 Accepted \\
\hline WHI ${ }^{\star}$ FRCASE*LOC & 0,201 & H4 Rejected \\
\hline
\end{tabular}

Source: primary data processed, 2021

Based on the table 3, it can be seen that the bystander effect variables did not significantly affect the financial statements fraud, because of its significance value $>0.05$ (0.225) so that $\mathrm{H} 1$ is rejected. While whistleblowing variables significantly influence the financial statement fraud because the significance value $<0.05(0.037)$, which means that $\mathrm{H} 2$ is accepted. In the relationship between the bystander effect and financial statements fraud, variable locus of control is able to moderate the influence between the two variables such as the significance value $<0.05(0.017)$ which means that $\mathrm{H} 3$ is accepted. However, the locus of control variable is not able to moderate the relationship between the whistleblowing and financial statement fraud because the results show that the significance value is $>0.05(0.201)$ so it can be concluded that $\mathrm{H} 4$ is rejected.

\subsection{Discussion}

The results show that $\mathbf{H}_{\mathbf{1}}$ is rejected, that meaning bystander effect does not significantly affect the financial statements fraud. Therefore, the presence or absence of a bystander does not affect the occurrence of fraudulent financial statements. The number of bystander groups in the company does not determine a person's tendency to commit financial statement fraud[20]. A good Internal Control System (SPI) will trigger the improvement of work and control systems that can reduce the chance of fraud [21].

The presence of a whistleblower, a fraudulent act will be quickly identified by other parties so that this can prevent the potential for fraudulent financial statements [4]. The test results indicate that $\mathbf{H}_{2}$ is accepted, which means whistleblowing negatively affect the financial statement fraud. The more someone who wants to become a whistleblower, the level of financial statement fraud will decrease.

The test results showed that $\mathbf{H}_{3}$ is accepted, which means that locus of control can strengthen the influence between the bystander effect on the financial statements fraud. Meanwhile the results of the testing indicate that $\mathbf{H}_{4}$ is rejected, which means the locus of control can not weaken the influence between whistleblowing on the financial reporting fraud. A person who knows that there has been a fraud but chooses to remain silent and intentionally leaves it alone or does not want to be involved in the case, which can disrupt his working position. Locus of control is an individual's belief in controlling an event that originates from within and outside himself [22]. Individual factors have an important role in influencing individual ethical behavior[23]. This relates to the two types of locus of control possessed by every human being, namely internal and external locus of control. People who have a higher inner locus of manipulate take delivery of as authentic with that they control what takes place to them. Meanwhile, human beings who have an exterior locus of manipulate consider that opportunity, fate, and different events determine what takes place to them.

\section{CONCLUSION}

Based on the outcomes of information analysis that has been carried out in this study, the following conclusions are received (1) the results of this find out about cannot take delivery of the first hypothesis, particularly the bystander impact has a fantastic effect on the prevalence of monetary announcement fraud, (2) the effects of this find out about take delivery of the $2 d$ hypothesis, particularly the whistleblowing system has a terrible effect on the occurrence of economic announcement fraud, (3) the consequences of this learn about accept the 0.33 hypothesis, particularly locus of manipulate can reasonable the influence of bystander effect on the economic announcement fraud, and (4) the outcomes of this learn about cannot receive the fourth speculation is that the locus of manage can average the have an effect on of whistleblowing system on the financial statement fraud.

Based on the conclusions, the following are some suggestions that can be considered for further research, namely to further examine the moderating effect of locus of control variables, both internal and external locus of 
control. In addition, it can also increase the number of samples, conduct mixed research methods to test other variables suspected of having a relationship with financial fraud, which are still in the experimental method.

\section{REFERENCES}

[1] S. Rahmayuni, "Peranan Laporan Keuangan dalam Menunjang Peningkatan Pendapatan Pada UKM," JSHP ( J. Sos. Hum. dan Pendidikan), vol. 1, no. 1, p. 93, 2017, doi: 10.32487/jshp.v1i1.239.

[2] D. Ratmono, Y. A. Diany, and A. Purwanto, "Dapatkah Teori Fraud Triangle Menjelaskan Kecurangan Dalam Laporan Keuangan?," J. Akunt. Dan Audit., vol. 14, no. 2, pp. 100-117, 2017, doi: 10.14710/jaa.14.2.100-117.

[3] M. A. Prayoga and E. Sudarmaji, "Kecurangan Laporan Keuangan Dalam Perspektif Fraud Diamond Theory: Studi Empiris Pada Perusahaan Sub Sektor Transportasi Di Bursa Efek Indonesia," J. Bisnis dan Akunt., vol. 21, no. 1, pp. 89-102, 2019, doi: 10.34208/jba.v21i1.503.

[4] N. Asiah and D. S. Rini, "Pengaruh Bystander Effect dan Whistleblowing Terhadap Terjadinya Kecurangan Laporan Keuangan,” Nominal, Barom. Ris. Akunt. dan Manaj., vol. 6, no. 1, 2017, doi: 10.21831/nominal.v6i1.14336.

[5] A. Azka, R. A. S. Surya, and A. Zarefar, "Pengaruh Bystander, Reporting Channel Administration, Perceived Personal Responsibillity Dan Perceived Seriousness Terhadap Whistleblowing Intention (Studi Empiris pada Perusahaan Perbankan yang berada di kota Pekanbaru)," JOM FEB, vol. 6, no. 1, pp. 1-15, 2019.

[6] J. B. Rotter, "Generalized Expectancies for Internal Versus External Control of Reinforcement," Psychol. Monogr. Gen. Appl., vol. 80, no. 1, pp. 128, 1966.

[7] L. K. Trevino, "Ethical Decision Making in Organizations: A Person-Situation Interactionist Model,” Acad. Manag. Rev., vol. 11, no. 3, pp. 601617, 1986.

[8] N. W. T. Respati, "Pengaruh Locus of Control Terhadap Hubungan Sikap Manajer, Norma-Norma Subyektif, Kendali Perilaku Persepsian, Dan Intensi Manajer Dalam Melakukan Kecurangan Penyajian Laporan Keuangan," J. Akunt. dan Keuang. Indones., vol. 8, no. 2, pp. 123-140, 2011, doi: 10.21002/jaki.2011.08.

[9] G. E. Jones and M. J. Kavanagh, "An Experimental Examination of The Effects of Individual and
Situational Factors on Unethical Behavioral Intentions in The Workplace," J. Bus. Ethics, vol. 15, pp. 511-523, 1996.

[10] L. K. Trevino and S. A. Youngblood, "Bad apples in bad barrels: A causal analysis of ethical decisionmaking behavior,” J. Appl. Psychol., vol. 75, no. 4, pp. 378-385, 1990.

[11] A. F. Novianti and N. H. Uswati Dewi, "An Investigation of the Theory of Planned Behavior and the Role of Tax Amnesty in Tax Compliance," Indones. Account. Rev., vol. 7, no. 1, pp. 79-94, 2017, doi: 10.14414/tiar.v7i1.961.

[12] M. C. Jensen and W. H. Meckling, "Theory of the Firm: Managerial Behavior, Agency Costs and Ownership Structure," J. financ. econ., vol. 3, no. 4, pp. 305-360, 1976, doi: http://dx.doi.org/10.1016/0304-405X(76)90026-X.

[13] K. M. Eisenhardt, “Agency Theory: An Assessment and Review," Acad. Manag. Rev., vol. 14, no. 1, pp. 57-74, 1989.

[14] Kasmir, Analisis Laporan Keuangan, 1st ed. Jakarta: RajaGrafindo Persada, 2013.

[15] A. Putri, "Kajian: Fraud (Kecurangan) Laporan Keuangan," J. Ris. Akunt. dan Komputerisasi Akunt., p. 2, 2012.

[16] R. C. Sari, Akuntansi Keperilakuan- Teori dan Implikasi. Yogyakarta: Penerbit ANDI, 2018.

[17] W. M. Hoffman and R. E. McNulty, "A Business Ethics Theory of Whistleblowing," J. Bus. Environ. Ethics. Bentley Univ. Waltham MA. USA, pp. 4559, 2008.

[18] M. A. Khan, "Auditors and Whistleblowing Law," Account. Today. April 2009, pp. 12-14, 2009.

[19] I. Ghozali, “Aplikasi Analisis Multivariate Dengan Program IBM dan SPSS 21," in Aplikasi Analisis Multivariate dengan Pogram IBM SPSS 21, 2013.

[20] S. Ayers and S. E. Kaplan, "Wrongdoing by Consultants: An Examination of Employees' Reporting Intentions," J. Bus. Ethics, vol. 57, no. 2, pp. 121-137, 2005.

[21] I. Ramadhany, "Pengaruh Sistem Pengendalian Intern, Asimetri Informasi, Kesesuaian Kompensasi dan Implementasi Good Corporate Governance Terhadap Kecenderungan Kecurangan Akuntansi (Studi Empiris pada Rumah Sakit Swasta yang ada di Pekanbaru)," JOM Fekon, vol. 4, no. 1, pp. 1253 1267, 2017.

[22] K. Duffy and E. Atwater, Psychology for Living: Adjustment, Growth, and Behavior Today - 8th 
edition. Upper Saddle River, NJ: Prentice Hall, Inc., 2005.

[23] A. A. Bawa and G. W. Yasa, "Efek Moderasi Locus of Pada Hubungan Otoritas Atasan dan Kecurangan Akuntansi," E-Jurnal Ekon. dan Bisnis Univ. Udayana, vol. 5, no. 5, pp. 1057-1086, 2016. 